\title{
POTENSI KAMPUNG NELAYAN GEDONGMULYO UNTUK DIKEMBANGKAN SEBAGAI DESA WISATA BAHARI DI KECAMATAN LASEM KABUPATEN REMBANG JAWA TENGAH
}

\section{Sugeng Santoso, Gunaldi, Ali Mustofa}

Pascasarjana Universitas Mercu Buana, Jakarta Indonesia

Email: sugeng.santoso@mercubuana.ac.id,gun.adek@yahoo.co.id, aliacm942@gmail.com

\begin{abstract}
Abstrak
Pembangunan kepariwisataan kawasan pesisir pada dasarnya adalah sebagai upaya untuk mengembangkan dan memanfaatkan obyek dan daya tarik wisata bahari yang terdapat diseluruh kawasan perairan Indonesia. Wisata bahari umumnya mempunyai sifat yang khusus dengan lokasi yang luasnya relatif terbatas, sehingga perlu dipikirkan daya dukung lingkungan untuk membangun fasilitas penopangnya. Kampung nelayan gedongmulyo yang mempunyai potensi daerahnya untuk diangkat sebagai destinasi wisata bahari yang ada di kabupaten Rembang merupakan daerah yang Potensi pesisir dan laut dengan berbagai kekayaan yang terkandung didalamnya yang dapat dimanfaatkan untuk tujuan wisata bahari, adapun dampaknya dapat memberikan kontribusi positif guna meningkatkan pendapatan daerah serta menunjang kegiatan di sektor informal dan jasa. Hal ini juga dilakukan guna meningkatkan potensi daerah dan juga bertujuan dapat memberikan peran aktif guna perencanaan pembangunan wilayah, serta meningkatkan taraf hidup masyarakat di lingkungan objek wisata yang akan dikembangkan. Pengembangan potensi tersebut dilakukan dengan tetap memperhatikan pembangunan berkelanjutan beserta potensi dan masalah yang dimiliki.
\end{abstract}

Kata Kunci: Potensi Kampung; Pembangunan berkelanjutan; Destinasi Wisata

\section{Abstract}

The development of tourism in the coastal area of Budiman is an effort to develop and utilize marine tourism objects and attractions throughout Indonesia's territorial waters. Marine tourism generally has a characteristic with a relatively limited area, so it is necessary to think about the carrying capacity of the environment to build supporting facilities (Suharsono et al, 1995a; 1995b). Gedongmulyo Fishing Village, which has the potential of its territory to be designated as a marine tourism destination in Rembang Regency, is an area that has coastal and marine potential with a variety of wealth contained in it that can be used for marine tourism purposes. regardless of the impact. can make a positive contribution to increasing local income and support activities in the informal and service sectors. This is also done in order to increase the potential of the region and also aims to provide an active role in regional development planning, as well

\footnotetext{
How to cite: $\quad$ Santoso. S., Gunaldi, Ali Mustofa (2021) Potensi Kampung Nelayan Gedongmulyo untuk Dikembangkan Sebagai Desa Wisata Bahari Di Kecamatan Lasem Kabupaten Rembang Jawa Tengah. Syntax Literate: Jurnal Ilmiah Indonesia, 6(12). http://dx.doi.org/10.36418/syntax-literate.v6i12.5205

E-ISSN: 2548-1398

Published by: Ridwan Institute
} 
as improve the standard of living of the community in the tourism object environment to be developed. This potential development is carried out by still paying attention to sustainable development and its potential and problems.

Keywords: Village Potential; Sustainable development; Tourism Destinations

Received: 2021-11-20; Accepted: 2021-12-05; Published: 2021-12-20

\section{Pendahuluan}

Keberadaan kawasan pesisir memiliki arti yang strategis karena merupakan daerah peralihan antara ekosistem darat dan laut serta memiliki potensi sumber daya alam dan lingkungan yang sangat kaya yang tercermin dari besarnya keanekaragaman hayati (Ristianti, 2015), wilayah pesisir memiliki potensi lain berupa keunikan dan keindahan alam yang dapat menjadi daya tarik wisata sehingga aktivitas pariwisata pun dapat dikembangkan dan menghasilkan dampak positif dengan ikut meningkatkan perekonomian kawasan. Pengembangan pariwisata pesisir sendiri pada dasarnya difokuskan pada pemandangan, karakteristik ekosistem, kekhasan seni budaya dan karakteristik masyarakat sebagai kekuatan dasar yang dimiliki oleh masing - masing daerah (Wakhidah, Dewi, \& Ristianti, 2014). Potensi pesisir dan laut dengan berbagai kekayaan yang terkandung didalamnya yang dapat dimanfaatkan untuk tujuan wisata bahari adalah kampung nelayan gedongmulyo yang mempunyai potensi daerahnya untuk diangkat sebagai destinasi wisata bahari karena desa gedongmulyo berdekatan dengan objek wisata sejarah didesa dasun yaitu situs dok kapal yang telah ada sejak jaman kerajaan demak (Nurhajarini \& Purwaningsih, 2015), belanda sampai penjajahan jepang dan di desa gedongmulyo juga terdapat wisata pantai caruban yang masih asri serta pantai karang jahe karena Pantai Karang Jahe dengan Pantai Caruban sebenarnya lokasinya berdekatan, hanya saja secara administratib pantai-pantai tersebut terletak di dua kecamatan yang berbeda. Pantai Karang Jahe atau Karang Jahe Beach terletak di di Desa Punjulharjo, Kecamatan Rembang, sedangkan Pantai caruban terletak di Desa Gedongmulyo, Kecamatan Lasem.

Dalam Rencana Program Jangka Menengah Daerah (RPJMD) tahun 2016 - 2021 Kabupaten Rembang Bab II hal. 11 No.7 tentang Kawasan Peruntukan Pariwisata terbagi menjadi pengembangan wisata alam, pengembangan wisata budaya, dan pengembangan wisata buatan manusia.

Begitu juga dalam Perda Kabupaten Rembang No. 12 tahun 2019 menetapkan Peraturan Daerah Tentang Rencana Induk Pembangunan Kepariwisataan Kabupaten Rembang Tahun 2019-2025.

Serta Peraturan Menteri Kebudayaan dan Pariwisata Nomor: Km. 67/Um.001/Mkp/2004 tentang Pedoman Umum Pengembangan Pariwisata menyatakan bahwa pembangunan pariwisata berkelanjutan adalah pembangunan yang mampu memenuhi kebutuhan wisatawan dan masyarakat didaerah tujuan saat ini dengan tetap menjaga dan meningkatkan kesempatan pemenuhan kebutuhan di masa yang akan datang. 


\section{Metode Penelitian}

Penelitian ini menggunakan pendekatan kualitatif dengan deskriptif kualitatif karena bermaksud memahami situasi sosial secara mendalam. Penelitian kualitatif menurut (Sugiyono, 2011) merupakan salah satu penelitian dengan tahapan yang lebih membutuhkan penyesuaian seperti tidak terfokus pada pelibatan perhitungan yang erat kaitannya dengan data numerik, tetapi lebih berdasar kepada informasi yang terekspresikan melalui kata-kata.

Tujuan penelitian adalah tersusunnya penyusunan sebuah desain perancangan masterplan penataan kampung nelayan Gedongmulyo Kecamatan Lasem Kabupaten Rembang untuk menjadi panduan dalam pengembangan sebuah objek destinasi wisata bahari sekaligus memperkuat identitas budaya, keunikan maupun kekhasannya.

Tempat penelitian adalah Desa Gedongmulyo, Kecamatan Lasem, Kabupaten Rembang Jawa Tengah adalah merupakan kampung nelayan yang terletak di pesisir pantai laut jawa. Sumber data yang dipergunakan adalah data sekunder, yaitu dokumen Perda, Permen, profil desa, serta jurnal atau literatur lainnya yang terkait dengan potensi pengembangan pariwisata bahari. Data primer berupa data langsung dari lokasi penelitian di lapangan mengenai perencanaan kawasan pariwisata yang didapat melalui observasi dan wawancara serta dokumentasi berupa foto maupun catatan.

Metode pengumpulan data lapangan menggunakan metode observasi, wawancara mendalam untuk menggali potensi wilayah, dan dokumentasi (Sidik, 2015). Metode wawancara dilakukan terhadap masyarakat, stakeholder, tokoh masyarakat, Wartawan, dan pihak pihak yang dipandang perlu dalam menggali potensi yang ada di kampung nelayan gedongmulyo yang akan dikembangkan menjadi desa wisata bahari.

Teknik analisa yang digunakan adalah analisa SWOT. Analisis SWOT adalah analisis kondisi internal maupun eksternal suatu organisasi yang selanjutnya akan digunakan sebagai dasar untuk merancang masterplan penataan kawasan wisata bahari. Analisis internal meliputi peniaian terhadap faktor kekuatan (Strength) dan kelemahan (Weakness). Sementara, analisis eksternal mencakup faktor peluang (Opportunity) dan tantangan (Threath) (Adam, 2018).

\section{Hasil dan Pembahasan}

\section{A. Analisis}

\section{Gambaran Umum}

Kampung nelayan Gedongmulyo yang terletak dipesisir pantai utara laut jawa secara administratif salah satu desa pada kecamatan Lasem kabupaten Rembang aktifitas warga adalah sebagai nelayan untuk laki-laki dan mengolah hasil laut untuk para wanita mengolah hasil laut seperti pembuatan peyek ikan, keripik ikan, serta banyak lagi. 


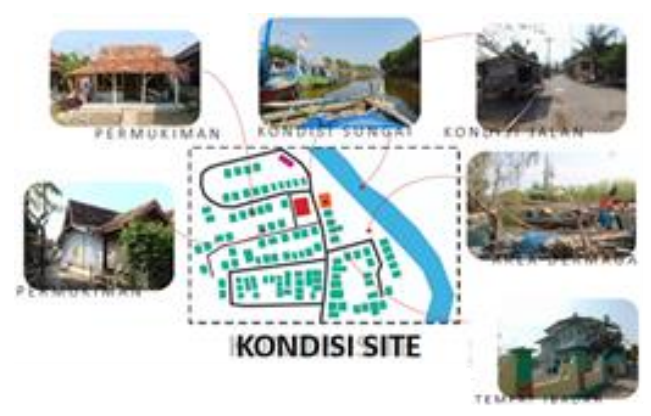

\section{Gambar 1 \\ Kondisi Site \\ Sumber: Survey Lapangan}

\section{Kondisi Inprastruktur Jalan}

Transportasi yang baik sangat berpengaruh terhadap kelancaran kegiatan perekonomian kota (Palilu, 2018). Sarana pendukung transportasi di Desa Gedung Mulyo adalah angkutan dan jalan yang menghubungkan antara desa satu dengan desa lain.

Di sisi yang lain dalam masing-masing kecamatan itu sendiri terdapat simpul-simpul desa. Dalam kaitannya dengan pergerakan penduduk, factor penduduk dan kegiatan dari luar (factor penarik eksternal). Kegiatan yang banyak mempengaruhi pergerakan penduduk tersebut adalah kegiatan perekonomian. Selain itu factor social budaya juga dapat mempengaruhi pola pergerakan penduduk tersebut. Kondisi jalan rata-rata menggunakan paving block mengingat kondisi lingkungan didaerah pesisir pantai kalau menggunakan perkerasan aspalt mudah rusak dikarenakan kalau terjadi rob air laut naik kepermukaan.

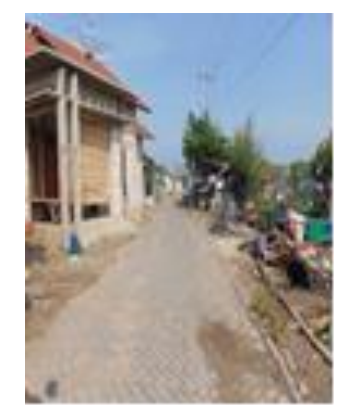

Gambar 2

Kondisi Jalan Lingkungan

Sumber: Survey Lapangan

\section{Kondisi Perahu Nelayan Bersandar}

Kawasan budidaya di Kabupaten Rembang berdasarkan ketentuan pasal 21 Perda Nomor 14 Tahun 2011 tentang Rencana Tata Ruang Wilayah (RTRW) Kabupaten Rembang Tahun 2011-2031. Kampung nelayan Gedongmulyo merupakan kawasan peruntukan perikan tangkap karena berada diperairan 
Kecamatan Lasem yang merupakan kawasan budidaya. Namun dalam hal ini kondisi kampung nelayan gedongmulyo dalam hal kondisi sarana dan prasarana tempat perahu bersandar tidak ada dan kondisi lingkungan sekitar aliran sungai juga tidak tertata dengan rapih.

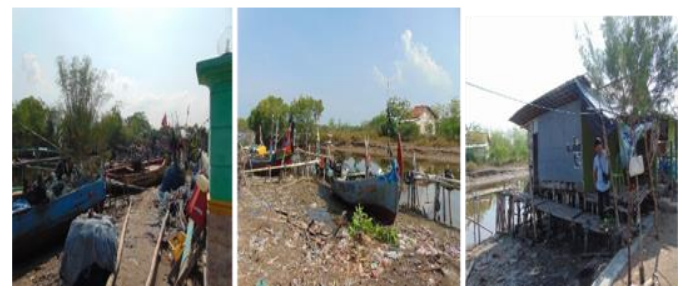

Gambar 3

Kondisi Perahu Nelayan

Sumber: Survey Lapangan

\section{Karakteristik Rumah}

Aspek arsitektural bangunan merupakan bagian dari perwujudan fisik dari kebudayaan, perilaku dan adat istiadat suatu masyarakat. Kebudayaan, adat istiadat/ kebiasaan perilaku, kepercayaan dan religi sebagai suatu bagian dari aktivitas manusia mempunyai hubungan timbal balik dengan lingkungan fisiknya. Arsirektur tradisional Rembang, seperti halnya arsitektur Jawa pada umumnya, identik dengan penampakan bentuk atap Joglo. Bentuk dasar Joglo di Jawa Tengah telah berkembang menjadi lima bentuk dasar (yang tercatat semenjak abad XIII).

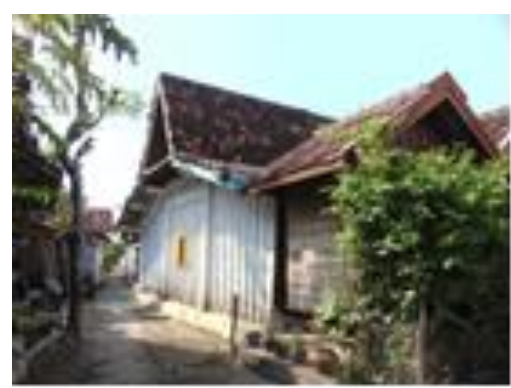

Gambar 4

Kondisi Rumah Tradisional

Sumber: Survey Lapangan

\section{Aksebilitas kampung}

Sesuai sifat kodrati manusia sebagai makhluk sosial, dalam pemenuhan kebutuhan hidup selalu berhubungan dengan anggota masyarakat yang lain. Hubungan ini mencakup penduduk dalam satu wilayah maupun dengan wilayah lain yang lebih luas. Untuk perjalanan menuju kampung nelayan Gedongmulyo dapat dilakukan lewat jalan darat dari jalan Raya Kragan-Rembang-Surabaya lalu masuk melalui jalan layur yang merupakan jalan desa yang hamper rata-rata jalan tersebut menggunakan material conblock. 


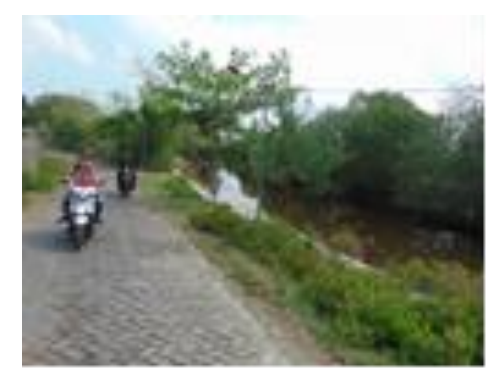

Gambar 5

Kondisi Aksebilitas Kampung

Sumber: Survey Lapangan

\section{Kondisi sungai dan aktifitas masyarakat}

Desa Gedung Mulyo khususnya di dukuh layur aktifitas masyarakat kesehariannya mayoritas adalah Nelayan untuk kaum bapak dan pemuda, sedang ibu-ibunya mengolah hasil laut misalnya di buat keripik, penyek dan lain lain. Sungai Dasun merupakan sungai utama di Kecamatan Lasem. Sungai ini membujur dari utara ke selatan dan bermuara di Laut Jawa. Keberadaan sungai ini dimanfaatkan oleh penduduk Desa gedongmulyo sebagai tempat lalu lintas perahu. Selain ditumbuhi pohon mangrove di kanan kirinya.

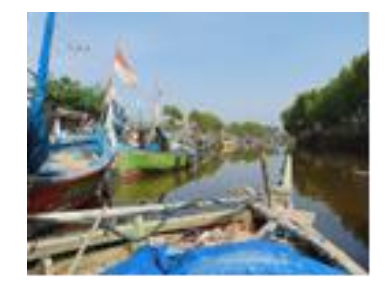

Gambar 7

Kondisi Sungai

\section{Identifikasi Potensi}

Sumber: Survey lapangan

Pada proses identifikasi potensi ini digunakan analisa deskriptif dengan menghubungkan teori yang ada dengan kondisi eksisting di Kampung gedongmulyo.

\begin{tabular}{ll}
\hline Variable & \multicolumn{1}{c}{ Analisa } \\
\hline Jenis & Salah satu kegiatan yang dilakukan masyarakat kampung \\
aktifitas & nelayan Gedongmulyo adalah menangkap ikan. Saat ini \\
masyarakat & kegiatan menangkap ikan dilakukan dengan cara yang \\
& tradisional. Masyarakat menangkap ikan dengan cara \\
& berkelompok, dengan menggunakan perahu tradisonal \\
& dengan diesel sebagai penggerak. Dan setelah melaut \\
& perahu disandarkan dipinggir sungai atau kali, sehingga \\
& tidak beraturan dan terkesan kumuh, dan perahu ini sebagai \\
& daya Tarik tersendiri untuk mode transportasi untuk \\
& menyusuri sungai dan samapi pesisir pantai untuk melihat \\
\hline
\end{tabular}




\begin{tabular}{ll}
\hline & keindahannya. \\
\hline Jenis & Pengelolaan hasil laut di kampung nelayan Gedongmulyo \\
kegiatan & juga masih tradisional. Kurangnya pengetahuan masyarakat \\
pengolahan & terkait tata cara penggunaan teknologi serta tidak tersedia \\
hasil laut & stand kios penjual hasil olahan laut. Selama ini masyarakat \\
& hanya menjualnya secara tradisional dan ini merupakan \\
& daya Tarik bagi wisatawan yang merupakan kekhasan \\
& kuliner dari pengolahan hasil laut. \\
\hline Jenis & Dikampung nelayan Gedongmulyo terdapat beberapa \\
bangunan & bangunan tradisional yang dipertahankan sebagai kekhasan \\
tradisional & (kearifan local) dan ini merupakan daya Tarik bagi \\
& wisatawan untuk menginap sehingga mengangkat \\
& pendapatan keluarga dan juga wisatawan dapat berbaur \\
dengan masyarakat di desa Gedongmulyo dapat juga dibuat \\
homestay sebagai penginapan yang yang berstandar \\
internasional dengan mencerminkan kearifan local.
\end{tabular}

\section{B. Pembahasan}

\section{Desain Perancangan}

Pada penelitian ini menggunakan teknik analisa SWOT untuk merumuskan Desain Perencanaan dan Perancangan di kampung nelayan Gedongmulyo. analisis SWOT adalah analisis kondisi internal maupun eksternal suatu organisasi yang selanjutnya akan digunakan sebagai dasar untuk merancang atau mendesain sebuah kampung menjadi desa wisata bahari. Analisis internal meliputi peniaian terhadap faktor kekuatan (Strength) dan kelemahan (Weakness). Sementara, analisis eksternal mencakup faktor peluang (Opportunity) dan tantangan (Threaths).

\begin{tabular}{|c|c|}
\hline Strength & Weekenss \\
\hline $\begin{array}{l}\text { - } \text { Masuk dalam Kawasan } \\
\text { - } \text { Mengembangan pariwisata } \\
\text { sebagarakat bermata pencahariah } \\
\text { - Memiliki potensi perikanan yang } \\
\text { cukup baik } \\
\text { - Memiliki industry pengolahan } \\
\text { ikan skala rumah tangga } \\
\text { - Dekat denagn objek wisata pantai } \\
\text { caruban, wisata sejarah desa } \\
\text { dasun. } \\
\text { - Membantu masyarakat membuka } \\
\text { usaha kuliner hasil laut } \\
\text { - Membantu masyarakat membuka } \\
\text { usaha penginapan } \\
\text { - Membantu masyarakat dalam } \\
\text { penyediaan usaha transportasi } \\
\text { laut. }\end{array}$ & $\begin{array}{l}\text { - Belum memiliki dermaga perahu } \\
\text { - Belum tersedianya akses menuju } \\
\text { Kawasan yang direncanakan } \\
\text { - Aliran sungai belum dilakukan } \\
\text { penataan dibagain bibir sungai kiri dan } \\
\text { kanan } \\
\text { - Infrastruktur yang minim } \\
\text { - Modernisasi perahu dengan } \\
\text { mempercantik bentuk perahu yang } \\
\text { dapat digunakan untuk transportasi } \\
\text { wisatawan dan menangkap ikan } \\
\text { - Modernisasi proses pengolahan hasil } \\
\text { laut agar lebih higensis. Pelatih } \\
\text { pengolahan hasil laut kepada } \\
\text { masyarakat. } \\
\text { - Penyediaan lahan untuk akses menuju } \\
\text { lokasi }\end{array}$ \\
\hline
\end{tabular}


- Menciptakan lapangan pekerjaan

- Kebersihan aliran sungai terjaga

- Wilayah menjadi lebih indah dan asri

- Wilayah tertata dengan baik

- Kesehatan masyarakat menjadi lebih baik, karena kebersihan terjaga

- Pendapatan ekonomi masyarakat meningkat.

\begin{tabular}{lll}
\hline \multicolumn{1}{c}{ Opportunity } & \multicolumn{2}{c}{ Threaths } \\
\hline - Peluang pariwisata & - Adanya persaingan dengan objek \\
- Pelungang pasar pengolahan hasil & $\begin{array}{l}\text { wisata bersejarah yang sudah } \\
\text { direncanakan terlebih dahulu }\end{array}$ \\
& laut & - Menumbuhan rasa kesadaran \\
- Peluang pasar kerajinan tangan & masyarakat untuk menjaga kebersihan \\
- Peluang pasar kuliner hasil laut & $\begin{array}{l}\text { sungai untuk tidak membuang sampah } \\
\text { - Adanya dukungan dari } \\
\text { pemerintah Kab. Rembang }\end{array}$ & $\begin{array}{l}\text { disungai. } \\
\text { - Peluang industry penginapan }\end{array}$ \\
- Dekat dengan objek wisata pantai \\
$\begin{array}{l}\text { dan lokasi wisata bersejarah } \\
\text { kecamatan Lasem. }\end{array}$
\end{tabular}

Dari analisa SWOT ini untuk mendapatkan potensi kampung nelayan gedong mulyo untuk dijadikan desa wisata bahari serta desain perancangannya.

\section{Pedestrian dan Vegetasi ditepi sungai}

Pedestrian ditepi sungai Dasun Desa Gedongmulyo sebagai sarana menyusuri sungai hingga tepi pantai dan bagian tepi kiri kanan di tanami tanaman peneduh dan pencegah erosi.

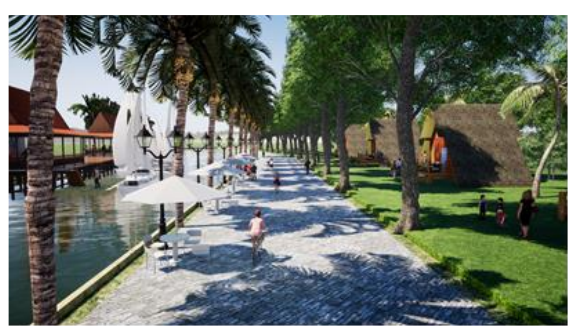

Gambar 8

Penataan Pedestrian

\section{Area Parkir}

Area parkir dengan perkerasan menggunakan grassblock dapat membantu proses penyerapan air, juga sebagai keseimbangan antara perkerasan dan penghijauan. 


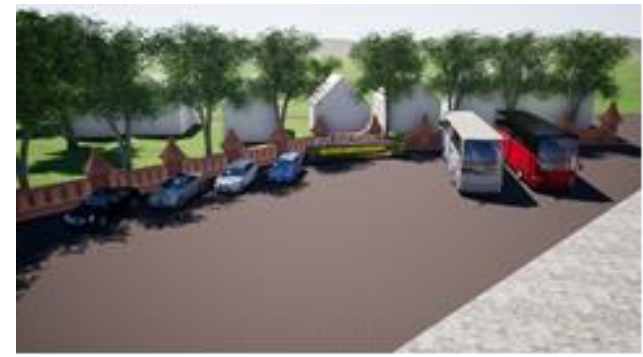

Gambar 9

Penataan Area Parkir

\section{Sarana Jalan dan Jembatan}

Perbaikan serta pembuatan inprastruktur jalan, drainase serta jembatan penghubung merupakan fasilitas utama dalam memberikan kenyamanan bagi wisatawan yang akan datang pada semua area di desa gedongmulyo dengan menggunakan paving block/grassblock.

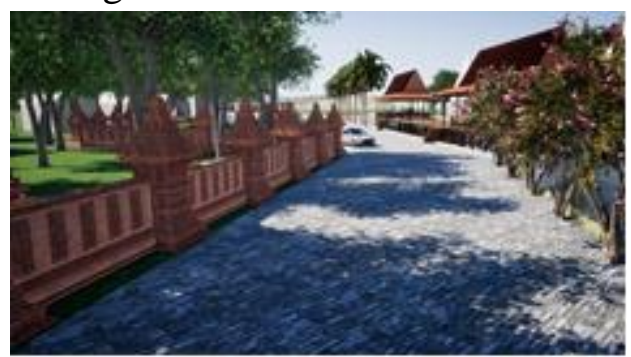

Gambar 10

Sarana dan Prasana pendukung

\section{Homestay}

Homestay merupakan salah satu sarana akomodasi didaerah tujuan ekowisata yang bernuansakan kedaerahan (tradisional), alami, bersih, sehat, aman, tertib dan ramah lingkungan (Rina, 2018). Bila homestay ini dikelola dengan professional akan menjadi nilai tambah tersendiri yang bisa memberikan dampak positif pada pelaksanaan pemasaran wisata didaerah tersebut

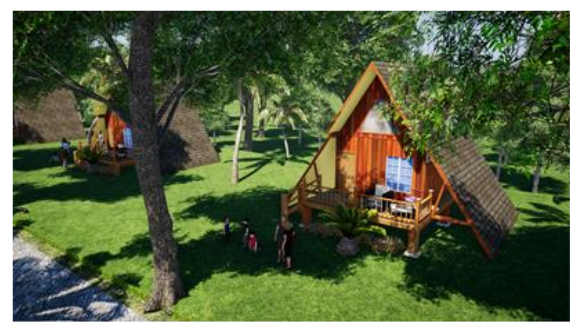

Gambar 11

Desain Homestay 


\section{Dermaga Perahu}

Dermaga adalah tempat perahu ditambatkan di tepian sungai (Arafat, Rachman, \& Paotonan, 2020). Dermaga adalah juga tempat berlangsungnya kegiatan naik turunnya orang atau penumpang dari dan ke atas perahu.

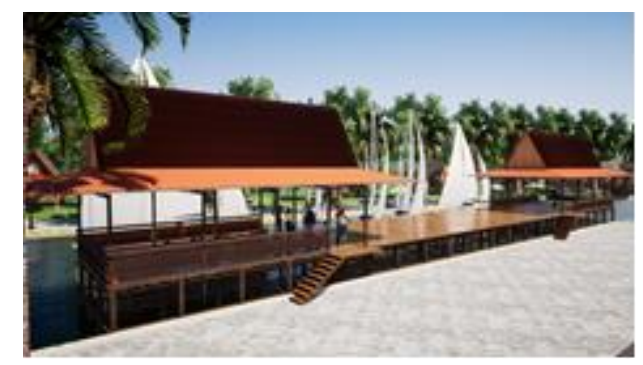

\section{Gambar 12}

\section{Fasilitas untuk UMKM}

\section{Desain Dermaga Perahu}

Pentingnya kita membuat bangunan fasilitas untuk mengakomodasi para pengiat produk home idustri baik produk olahan maupun produk kerajinan, dan ini dibuat untuk memfasilitasi usaha yang bergerak dalam perniagaan segala macam makanan produk olahan hasil laut, minuman serta produk kerajian inilah sebuah usaha yang juga dikategorikan sebagai satu bagian dari jenis usaha UMKM. Karena karakter niaga biasanya masih berupa usaha mikro kecil (Suci, 2017).

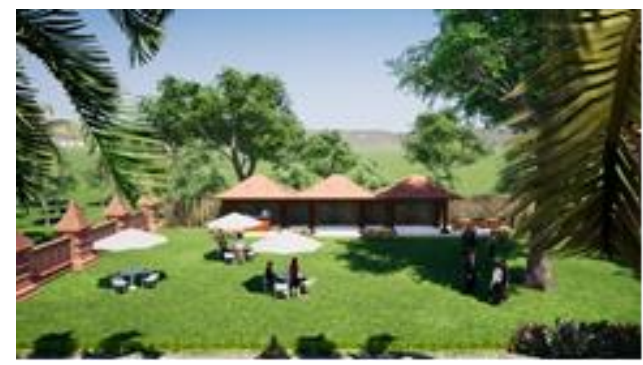

Gambar 13

Fasilitas Perniagaan UMKM

8. MasterPlan Penataan Kawasan Desa Wisata Bahari Gedongmulyo

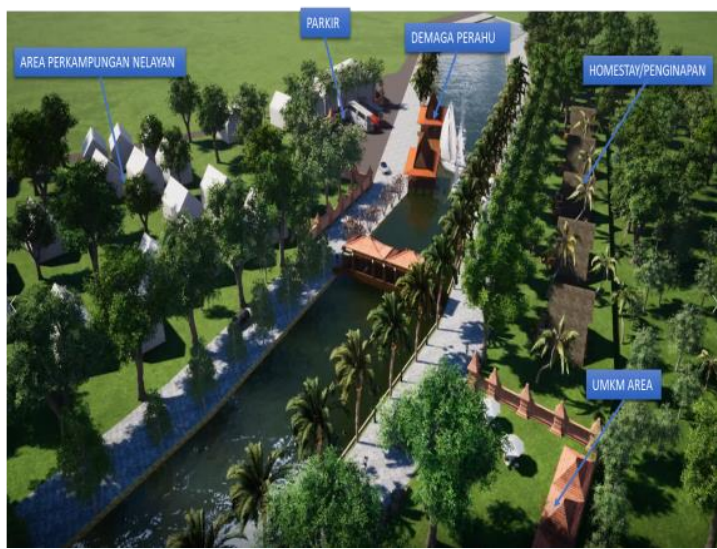

Gambar 14

MasterPlan Penataan Kawasan Desa Wisata Bahari Gedongmulyo 
Sugeng Santoso, Gunaldi, Ali Mustofa

\section{Kesimpulan}

Terwujudnya program fisik sarana dan prasarana serta rencana dan program kepariwisataan marintim dalam Penyusunan Masterplan dan DED (Detail Engineering Design) Desa Gedongmulyo Kecamatan Lasem Kabupaten Rembang, sebagai sasaran utama serta dapat membatu pemerintah daerah dalam memberikan konsep penataan kampung nelayan Gedongmulyo untuk diangkat potensi kampungnya menjadi destinasi wisata bahari sehingga terwujudnya kepariwisataan yang berbasis budaya, kemasyarakatan dengan tetap memperhatikan kelestarian lingkungan sehingga dapat memperluas lapangan pekerjaan dan kesempatan berusaha dalam rangka meningkatkan kesejahteraan masyarakat. 


\section{BIBLIOGRAFI}

Adam, Muhammad Brian. (2018). Strategi Pengembangan Pariwisata Pesisir Di Kawasan Taman Wisata Pantai Ngliyep Kabupaten Malang. Institut Teknologi Sepuluh Nopember. Google Scholar

Arafat, Andi Muhammad Alfian, Rachman, Taufiqur, \& Paotonan, Chairul. (2020). Tinjauan Aspek Keselamatan Dermaga Kapal Barang Pelabuhan Paotere Makassar. Sensistek: Riset Sains Dan Teknologi Kelautan, 126-131. Google Scholar

Nurhajarini, Dwi Ratna, \& Purwaningsih, Ernawati. (2015). Akulturasi lintas zaman di lasem: perspektif sejarah dan budaya (kurun niaga-sekarang). Fibiona. Google Scholar

Palilu, Aram. (2018). Analisis Pengaruh Pembangunan Infrastruktur Transportasi Terhadap Produk Domestik Regional Bruto Kota Ambon. Jurnal Buletin Studi Ekonomi. Vol, 23(2). Google Scholar

Rina, Sri Febda. (2018). Fasilitas Objek Wisata Dalam Pengembangan Desa Wisata: Kasus Bono di Kecamatan Taluk Meranti Kabupaten Pelalawan. Jurnal Daya Saing, 4(3), 371-380. Google Scholar

Ristianti, Novia Sari. (2015). Pengembangan Konsep Wisata Apung Kampung Nelayan Pesisir Balikpapan. Ruang, 1(1), 31-40. Google Scholar

Sidik, Fajar. (2015). Menggali potensi lokal mewujudkan kemandirian desa. JKAP (Jurnal Kebijakan Dan Administrasi Publik), 19(2), 115-131. Google Scholar

Suci, Yuli Rahmini. (2017). Perkembangan UMKM (Usaha mikro kecil dan menengah) di Indonesia. Cano Ekonomos, 6(1), 51-58. Google Scholar

Sugiyono. (2011). Metode Penelitian Kuantitatif. Bandung: Alfabeta.

Wakhidah, Kurniawati, Dewi, Santy Paulla, \& Ristianti, Novia Sari. (2014). Bentuk Pengembangan Pariwisata Pesisir Berkelanjutan Di Kabupaten Pekalongan. Ruang, 1(2), 261-270. Google Scholar

\section{Copyright holder:}

Sugeng Santoso, Gunaldi, Ali Mustofa (2021)

First publication right:

Syntax Literate: Jurnal Ilmiah Indonesia

This article is licensed under:

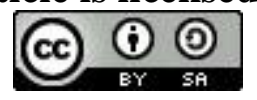

